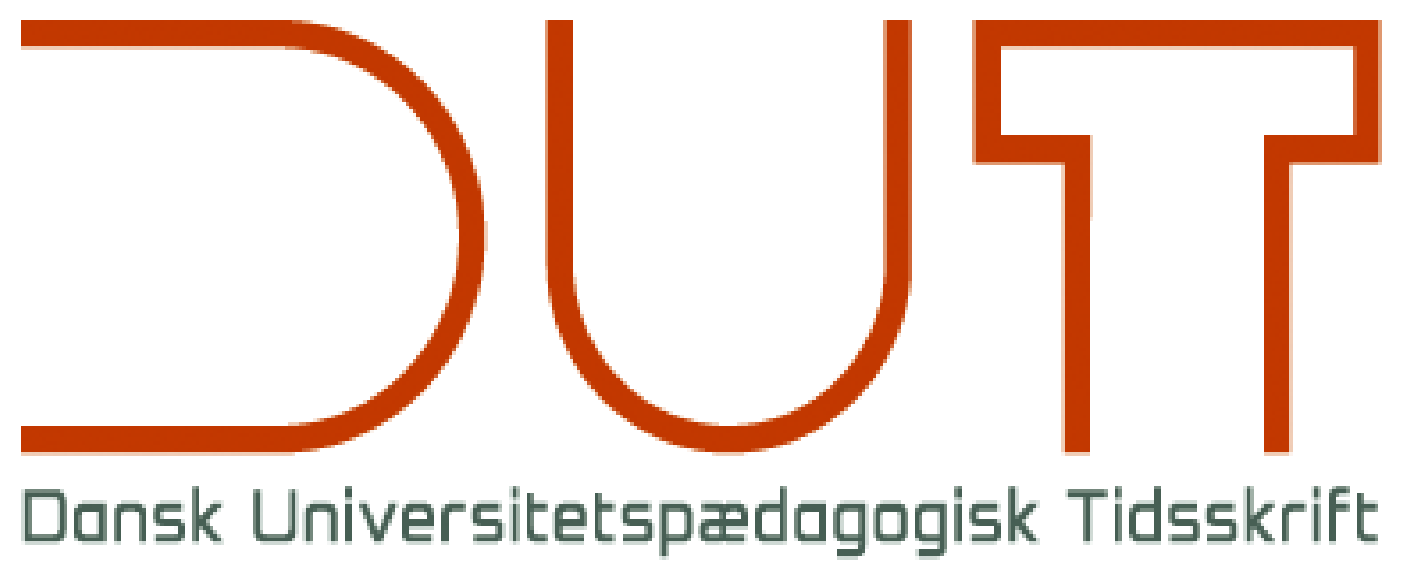

Universitetspædagogikum

Årgang 13 nr. 25 / 2018

Titel

Barrierer for det gode ph.d.-forløb og udvikling af et cafétilbud i biblioteket

Forfattere

Sidetal

Lone Bredahl Jensen, Katrine Astrup Jacobsen og Kamilla Jensen Husen

$71-90$

Udgivet af

Dansk Universitetspædagogisk Netværk, DUN

URL

> http://dun-net.dk/

Betingelser for brug af denne artikel

(c) Copyright
Denne artikel er omfattet af ophavsretsloven, og der må citeres fra den. Følgende betingelser skal dog være opfyldt:

- Citatet skal være i overensstemmelse med "god skik"

- Der må kun citeres „i det omfang, som betinges af formålet“

- Ophavsmanden til teksten skal krediteres, og kilden skal angives ift. ovenstående bibliografiske oplysninger.

DUT og artiklens forfatter 


\section{Barrierer for det gode ph.d.-forløb og ud- vikling af et cafétilbud i biblioteket}

Lone Bredahl Jensen, forskningsbibliotekar, Syddansk Universitetsbibliotek

Katrine Astrup Jacobsen, forskningsbibliotekar, Syddansk Universitetsbibliotek

Kamilla Jensen Husen, forskningsbibliotekar, Syddansk Universitetsbibliotek

\section{Faglig artikel, fagfællebedømt}

Denne artikel formidler et projekt, der blev gennemført i Syddansk Universitetsbibliotek for at udvikle et støttetilbud til ph.d.-studerende. Projektet skulle dels afdakke interessen, dels udvikle tilbuddets noermere form og indhold. En bagvedliggende tanke var, at tilbuddet - for at blive en succes - skulle adressere de barrierer, ph.d.-studerende oplever i deres ph.d.-forløb.

Personlige interviews med ph.d.-studerende pegede på dårlig vejlederrelation, undervisningspres og manglende kendskab til egen organisation og rettigheder som nogle af de oplevede barrierer. Konsekvenserne var bl.a. oplevede dårlige kompetencer $i$ tidsstyring og informationssøgning samt, på den psykosociale side, ensomhed, faglig usikkerhed og dårlig trivsel.

På den baggrund har biblioteket udviklet et cafétilbud med det formål at understøtte fagligt og socialt netvoerk blandt ph.d.-studerende på tvaers af fagområder. Det er forventningen, at projektets metode og resultater kan vare til inspiration for andre, der er i berøring med studerende og ph.d.-studerende, f.eks. gennem vejledning eller andre supportfunktioner på videregående uddannelsesinstitutioner.

\section{Introduktion}

Biblioteket er jævnligt i kontakt med ph.d.-studerende, som skal have hjælp til litteratursøgning, på kurser i ansvarlig videnskabelig praksis mv. Ofte fører disse møder til længere samtaler, der bevæger sig langt ud over det oprindelige emne, og som antyder en grundlæggende stor tillid ikke bare til biblioteket som institution, men også til de enkelte medarbejdere. Samtidig har flere medarbejdere i biblioteket, herunder forfatterne til denne artikel, personlige erfaringer fra eget ph.d.-forløb. Ad hocobservationer fra disse to 'platforme' satte gang i projektet: Hvordan kan biblioteket understøtte et godt ph.d.-forløb? Kan biblioteket bidrage til at reducere ensomhedsfølelsen og samtidig adressere nogle af de udfordringer, ph.d.-studerende møder, inden for rammerne af bibliotekets kerneydelser? Ideen om at lancere en ph.d.-café opstod, og projektet blev født. Ph.d.-caféen var fra starten tænkt som en platform til netværk og metafaglig refleksion, og det var en hovedtanke, at aktiviteten skulle 
supplere - ikke konkurrere med - det faglige uddannelsesforløb, der i forvejen ligger i et ph.d.-studium.

Flere end nogensinde er indskrevet som ph.d.-studerende på danske uddannelsesinstitutioner (Danske Universiteter, 2017). Ph.d.-graden er den højeste formaliserede akademiske uddannelse, man kan opnå i det danske uddannelsessystem. Et ph.d.studie er berammet til tre år, og inden for den tidsramme skal den ph.d.-studerende kvalificere sig til højeste faglige niveau ved at fordybe sig fagligt og producere en afhandling på videnskabeligt niveau. I ph.d.-studiet indgår også et mere formelt uddannelsesforløb gennem kurser og miljøskifte samt pligt til at påtage sig undervisnings- og/eller formidlingsopgaver, tilsammen svarende til et års arbejde. Elementerne i ph.d.-studiet er regulerede gennem ph.d.-bekendtgørelsen (Uddannelses- og Forskningsministeriet, 2013).

Omkring hver femte fuldfører ikke ph.d.-studiet, men falder fra undervejs, inden afhandlingen skal indleveres (Uddannelses- og Forskningsministeriet, 2015). En tidligere national undersøgelse af årsager til frafald peger særligt på vejleder og et stærkt fagligt miljø som vigtige faktorer for at gennemføre (Universitets- og Bygningsstyrelsen, 2007). Meget tyder dog på, at dette ikke er hele forklaringen. Den hidtil mest omfattende kvalitetsundersøgelse på området viser, at mange særligt inden for samfundsvidenskab og humaniora føler sig ofte ensomme på arbejdspladsen og alene med deres projekt uden den nødvendige sparring (hhv. 18\% og 22\%) (Herrmann, Wichmann-Hansen \& Jensen, 2014).

Universitetsbiblioteker er videninstitutioner, der servicerer ansatte og studerende med faglige materialer og ydelser, der kan indgå i universitetets videnskabelige produktion og undervisning. Universitetsbibliotekets traditionelle kerneydelse er at stille materialer (i biblioteksverdenen kaldet 'informationsressourcer') til rådighed for studerende og ansatte og bidrage til uddannelsen af bibliotekets brugere $\mathrm{i}$ at finde og udvælge blandt de tilgængelige informationer og materialer (i biblioteksterminologi: 'informationskompetence'). Derudover bidrager biblioteket med en række specialydelser målrettet bestemte brugergrupper, f.eks. systematiske reviews eller bibliometriske analyser (forskere) eller undervisning i referencehåndtering og opgaveskrivning (studerende). Universitetsbiblioteket er således en grundlæggende støttefunktion for både forskning og uddannelse. Spørgsmålet er, om biblioteket også bør udfolde sig som understøttende funktion på mere 'bløde' trivselsparametre. I givet fald bør biblioteket utvivlsomt kommunikere hensigten meget tydeligt og være opmærksom på at undgå konkurrence med andre tiltag.

Ph.d.-studerende er under uddannelse til forskere og befinder sig i overgangen mellem bibliotekets store klassiske brugergrupper - de indskrevne bachelor- og kandidatstuderende og 'forskningen'. Ph.d.-studerende er i et akademisk dannelsesforløb, hvor de dels skal lære at mestre forskningen som disciplin, dels skal finde deres pro- 
fessionelle og personlige arbejdsidentitet. Som ph.d.-studerende er man ofte også rollemodel for universitetets yngre studerende, og man indgår som en væsentlig del af fødekæden for universitetets næste generation af forskere og undervisere. Præcis denne overgangsposition gør ph.d.-studerende til en særligt interessant målgruppe for universitetsbiblioteket. Samtidig viser en tidligere undersøgelse af ph.d.studerendes informationskompetencer, at universitetsbiblioteker med fordel kan tilbyde faciliteter specifikt for netop ph.d.-studerende, og at bibliotekerne generelt bør have mere fokus på denne brugergruppe (Drachen, Larsen, Gullbekk, Westbye \& Lach, 2011). Udover de typiske kurser i informationssøgning og andre redskaber kan biblioteket via sin særlige position på universitetet fungere som en form for helle i hverdagen. Til arrangementer på biblioteket skal de ph.d.-studerende ikke stå til ansvar over for vejleder og institut, men kan mødes mere frit og på tværs af fag. Derfor er det også oplagt, at biblioteket faciliterer forskellige former for oplæg og workshops, som kan understøtte ph.d.-studerende både i forhold til trivsel og i forhold til arbejdet med deres ph.d.-projekt. Netop pga. deres særlige overgangsstatus benytter ph.d.-studerende sig typisk ikke af den traditionelle studievejledning, som er rettet mod BA- og kandidatstuderende. Samtidig har biblioteket en personalegruppe, som selv har erfaring med forskeruddannelsesforløb, og som derfor kan tilbyde en forståelse for de overordnede problemstillinger, som de ph.d.-studerende kan møde undervejs.

Ph.d.-studerende går ind i et ph.d.-forløb af mange årsager. For de fleste vejer interessen for at forske og karrieremuligheder tungt (Uddannelses- og Forskningsministeriet, 2017b; 2017a; Herrmann, Wichmann-Hansen \& Jensen, 2014). Efter Globaliseringsaftalen i 2006 kom der en markant stigning i optaget på landets universiteter (optaget steg fra 1.210 nye ph.d.-studerende i 2003 til 2.628 nye indskrevne i 2010, en stigning på 217\%). Optaget er senere stagneret lidt (2.477 blev optaget i 2014 (Danmarks Statistiks ph.d.-register; Uddannelses- og Forskningsministeriet, 2017b)). Uanset stagnationen er der i dag langt flere ph.d.-studerende på danske universiteter end nogensinde før. Dette giver udfordringer både for de faglige miljøer, der skal rumme de ph.d.-studerende, for ph.d.-skolerne, der skal administrere ph.d.uddannelsen, og for servicefunktioner rundt om på universiteterne, der på forskellig vis støtter op om ph.d.-forløbet, eksempelvis pædagogiske enheder, it-afdelinger, bibliotek og HR.

I modsætning til f.eks. i USA, hvor frafaldet er på over fyrre procent (Gardner \& Mendoza, 2010), er frafaldet på danske ph.d.-uddannelser forholdsvis lille, også set over den periode, hvor tilgangen for alvor steg. Udgangspunktet for denne artikel og projektet bag er derfor heller ikke primært, hvor mange ph.d.-studerende der kommer igennem et ph.d.-forløb, men hvordan de kommer igennem, og hvordan biblioteket kan hjælpe dem bedre igennem. 
Hvad er barriererne for et godt ph.d.-forløb set med de ph.d.-studerendes egne øjne? Hvordan kan biblioteket byde ind? Med disse forhold kortlagt vil det være muligt at udvikle et servicetilbud til ph.d.-studerende, som opfylder et reelt oplevet behov, dvs. et servicetilbud, som ph.d.-studerende både vil finde relevant, som de også i praksis vil benytte sig af, og som potentielt kan medvirke til at skabe bedre ph.d.forløb.

I det følgende præsenterer vi fremgangsmåde for og hovedresultater af det udviklingsprojekt, vi har gennemført i regi af biblioteket for at undersøge og udvikle cafétilbuddet. Derefter beskrives og diskuteres det cafétilbud, der er realiseret på baggrund af projektet.

\section{Bibliotekets udviklingsprojekt}

Projektet trækker på tankegangen i new product development-litteraturen, hvor brugerinddragelse ses som en kritisk succesfaktor (Cooper \& Kleinschmidt, 1995; Ernst, 2002). Her er filosofien dels, at et nyt produkt (herunder også en serviceydelse) må opfylde et behov i målgruppen, dels at man som led i produktudviklingen må søge indsigt i og inddrage brugernes behov, erfaringer og forventninger.

Projektet har fulgt udviklingsmodellen i figur 1. Ideen er kvalificeret ved at gennemføre en interviewundersøgelse lokalt på Syddansk Universitet (SDU). Med udgangspunkt i viden om de ph.d.-studerendes oplevede barrierer for et godt ph.d.-forløb har vi efterfølgende udviklet det konkrete tiltag. Konceptet mht. form, frekvens og rammer i øvrigt baserer sig også direkte på de input, vi har fået fra de interviewede ph.d.-studerende. Endelig er ph.d.-caféen implementeret.

Sideløbende er der også gennemført en rundspørge med andre universitetsbiblioteker, da vi ønskede at inddrage eventuelle erfaringer med lignende tiltag. Denne afrapporteres ikke her, da erfaringerne med lignende tiltag viste sig meget begrænsede.

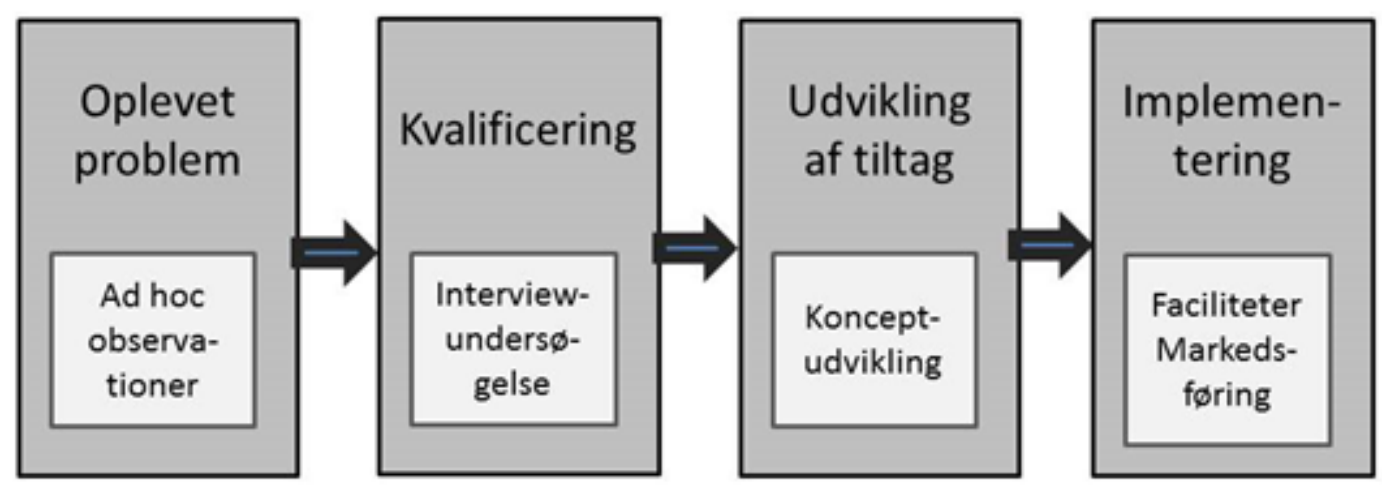

Figur 1. Udviklingsmodel 


\section{Interviewundersøgelsen}

Som led i udviklingen af cafetilbuddet gennemførte vi semi-strukturerede interviews med ph.d.-studerende indskrevet ved SDU. Formålet med undersøgelsen var dels at få dybere indsigt i danske ph.d.-studerendes oplevede barrierer for et godt ph.d.forløb for at kunne adressere disse i et kommende organiseret tilbud, dels at kvalificere tilbuddets nærmere form og indhold. Første del af interviewet (oplevede barrierer for ph.d.-forløbet) blev gennemført med inspiration fra means-end teori og laddering.

\section{Means-end teori og laddering}

Means-end teori har udgangspunkt i kognitiv psykologi og beskriver på et individuelt plan, hvordan en person mentalt kobler opfattede egenskaber ved et produkt eller en situation til livsværdier gennem opfattede selvrelevante konsekvenser (Gutman, 1982; 1997; Orsingher, Marzocchi \& Valentini, 2011). Teorien kan dels tages som udtryk for, hvordan værdier fungerer som abstrakte motiver for bestemte forbrugsvalg, dels bruges til at vise hvordan forbrugsrelateret viden er organiseret i den menneskelige hukommelse. Laddering er den specifikke interview- og analysemetode, der er knyttet til teorien, og hvor man gennem semistrukturerede, hierarkiske spørgsmål afdækker interviewpersonens 'associationskæder' (fra egenskaber over konsekvenser til værdier). I den efterfølgende analyse indholdskodes elementerne, og deres overordnede temaer og forbindelser præsenteres sluttelig i grafiske kort, normalt over grupper af interviewpersoner (kaldet hierarkiske værdikort; Miles \& Rowe, 2004).

Baggrunden for at bruge means-end teori og laddering i denne sammenhæng er dels, at teorien giver en teoretisk ramme både for at forstå barriererne for et godt ph.d.-forløb set fra den ph.d.-studerende selv (gennem oplevede selvrelevante konsekvenser og evt. uindfriede livsværdier), dels at interviewmetoden giver mulighed for at opnå og præsentere dybdegående indsigt på en relativt effektiv måde i modsætning til klassiske kvalitative undersøgelsesmetoder, der typisk er meget tidskrævende at gennemføre.

\section{Interviewpersoner}

Interviewundersøgelsen blev gennemført med ph.d.-studerende på de fakulteter på SDU, hvor der ikke i forvejen er fungerende ph.d.-klubber ${ }^{1}$. I alt 12 personer blev interviewet, fordelt med fire fra hhv. det samfundsvidenskabelige fakultet, det humanistiske fakultet og det tekniske fakultet. Alle var i anden halvdel af deres ph.d.-

\footnotetext{
${ }^{1}$ Ph.d.-klubberne er lokalt drevne studenterforeninger, der afholder regelmæssige aktiviteter også med henblik på at fremme sociale relationer. Disse ønskede vi ikke at komme til at sende signaler om at ville konkurrere med.
} 
studie. Interviewpersonerne blev udvalgt fra navnelister, som vi modtog fra fakulteternes ph.d.-skoler eller forskerstøtteenhed. Udvælgelsen skete tilfældigt (efter alfabetet) under hensyn til spredning på køn og institutter under fakulteterne. To afslog deltagelse ved første kontakt, begge med henvisning til manglende tid. I disse tilfælde blev nye interviewpersoner rekrutteret. Interviewene blev af praktiske årsager gennemført på dansk. Der blev derfor udelukkende rekrutteret blandt dansktalende ph.d.-studerende.

Alle interviewpersoner har frivilligt givet tilsagn om deltagelse og har frivilligt givet tilladelse til at videregive de indhentede informationer $\mathrm{i}$ anonymiseret form.

Interview og analyse

I første del af interviewet blev interviewpersonerne bedt om at nævne de forhold, som de mente, havde påvirket deres ph.d.-forløb. For hvert forhold blev der derpå spurgt ind til oplevede konsekvenser og til, hvordan forholdet - gennem de oplevede konsekvenser - havde påvirket interviewpersonens mere overordnede livsværdier. Forbindelsen fra konkrete forhold ved ph.d.-studiet over oplevede konsekvenser og til værdier definerer en 'værdikæde'. Denne interviewteknik giver brugerindsigt 'i dybden' og afdækker også årsager til, at bestemte forhold opleves som fremmere eller hæmmere af ph.d.-forløbet.

I anden del blev deltagerne forelagt ideen om en café-aktivitet for ph.d.-studerende og bedt om at forholde sig til grundideen, målgruppe, frekvens, form og indhold.

Første del blev anvendt til at få indsigt i barrierer for det gode ph.d.-forløb for at kunne uddrage konkrete ideer til emner, der med fordel kan adresseres i en ph.d.café. Anden del fungerede som en åben samtale, som havde til formål at vurdere interessen for ideen om café-aktiviteter for ph.d.-studerende og indholdsmæssig/praktisk kvalificering af samme.

Alle interviews blev gennemført af to personer fra projektgruppen, med én som gennemgående interviewer, og en som notattager. I noterne blev nævnte egenskaber, konsekvenser og værdier registreret i et skema, der også viste deres indbyrdes nævnte forbindelser. Data blev efterfølgende for hver interviewperson kategoriseret i hhv. egenskaber, konsekvenser og værdier, indholdskodet i mere generelle kategorier, og registreret med deres italesatte forbindelser. Derpå blev 'associationskæderne' præsenteret visuelt i grafiske kort, ét pr interviewperson. Kortene blev udarbejdet af projektgruppen og er efterfølgende individuelt blevet valideret af hver enkelt interviewperson. Kortene fremgår af bilag $1 .^{2}$

\footnotetext{
${ }^{2}$ Nærmere oplysninger om interviewundersøgelsens metode og resultater kan rekvireres ved henvendelse til forfatterne.
} 


\section{Resultater: Barrierer for et godt ph.d.-forløb}

En lang række forhold viste sig som barrierer for et godt forløb, enten ved at de blev nævnt direkte som hæmmere af ph.d.-forløbet eller ved, at de oplevede konsekvenser viste sig at være negative i det videre interview.

Langt de fleste havde både gode og dårlige ting at fortælle om deres ph.d.-forløb (en enkelt havde kun positive oplevelser; en enkelt nævnte kun hæmmende forhold). En støttende vejleder, miljøskifte, ph.d.-kurser, videre arbejde med specialeemne, undervisnings- og vejlederopgaver samt kollegaer blev fremhævet som forhold, der fremmede et godt ph.d.-forløb. Vejlederen er indgangen til kontakter i miljøet og kan give faglig sparring, noget, der betragtes som vigtigt for at kvalificere den faglige del af afhandlingen og opnå faglig selvsikkerhed, men som også sættes i relation til et længere sigte, nemlig ift. at kvalificere sig til en videre forskningskarriere. Der er ikke entydige ønsker til vejlederen. For nogle er det vigtigt, at vejlederen blander sig mindst muligt og giver frihed til selvstændigt arbejde, med den faglige fordybelse, glæde og selvbestemmelse samt fleksibilitet i forhold til familie, det fører med sig. For andre er det tydeligvis ønskeligt med mere løbende tæt dialog, ikke blot i forhold til det faglige og sparring på ideer men også ift. hjælp med tidsstyring/deadlines og for at stimulere fremdrift i arbejdet med afhandlingen. De negative konsekvenser $i$ en dårlig vejlederrelation, herunder også en utilgængelig vejleder, er tydelige; man oplever at mangle hjælp til at navigere inden for sit felt og hindres derved i den nødvendige/ønskede faglige selvsikkerhed. Nogle oplever også dårlig trivsel pga. vejleders oplevede dobbeltrolle, fx hvis vejleder samtidig er studieleder eller leder af det (eksternt finansierede) projekt, der også finansierer ph.d.-studiet. I førstnævnte tilfælde kan den ph.d.-studerende, i kombination med ikke at kende sine rettigheder, opleve at blive 'tvunget' ud i stor undervisningsbelastning, hvilket tager tid fra arbejdet med afhandlingen. I sidstnævnte tilfælde kan der komme faglig konflikt pga. indbyggede forventninger i det større forskningsprojekt om brug af bestemt forskningsmetode eller tilgang, hvilket, uforløst, hæmmer den ph.d.-studerendes mulighed for at tage ansvar og opbygge sin egen faglighed. Forholdet til vejlederen er i det hele taget udfordrende pga. den skæve magtbalance, da vejlederen ofte har stor magt over den studerendes skæbne.

Miljøskifte, kurser og undervisning/formidling er formelt indbyggede elementer i ph.d.-uddannelsen. Miljøskiftet ses, i lighed med vejleder, som en indgang til fagligt fællesskab og fordybelse og dermed opbygning af faglighed, der kan kvalificere en som forsker. Samtidig betragtes miljøskiftet som en kilde til uafhængighed og en oplevelse, der, tilrettelagt rigtigt, giver personligt udbytte og bidrager til hele familiens trivsel.

Interessant nok nævnes de kurser, der er formelt indbygget i ph.d.-uddannelsen, stort set ikke. Dette betyder ikke nødvendigvis, at kurserne ikke opfattes som vigtige 
rent fagligt, men kurserne synes ikke - samlet set og her henimod afslutningen af ph.d.-studiet - at opleves at have den store betydning for selve 'flowet' i projektet (som fremmende eller hæmmende).

Den kompetence, der opnås ved selv at undervise, ses derimod som en fordel, både ift. fremtidig karriere og, hvis man er så heldig at undervise i fag, der er relevante for afhandlingen, også for ideer og udvikling af afhandlingen. Samtidig kan undervisningen opleves som produktivt (i modsætning til arbejdet med afhandlingen) og bidrage til personlig tilfredsstillelse i form af glæde og en følelse af at 'give nogen noget'. Undervisningen er dog et tveægget sværd, for opgaven opleves samtidig som en tidssluger, hvor man særlig i starten må bruge meget tid på forberedelse og dermed mister tid til arbejdet med afhandlingen. Dette giver oplevelsen af dårligere muligheder for at blive færdig til tiden og en følelse af stress.

Interviewet viste, at ph.d.-forløbet kunne være fremmende eller hæmmende for udfoldelsen af flere centrale livsværdier. De nævnte mere overordnede livsværdier spændte vidt fra tryghed til uafhængighed, fra altruisme til perfektionisme, og fra karriere til samfundsnytte ${ }^{3}$. Disse par skal ikke betragtes som modsætningspar, men viser, at motiverne er mange og forskelligartede for ph.d.-studerende. I de negative associationskæder var to værdier dominerende, nemlig: trivsel og viden/faglighed. De ph.d.-studerende oplevede særligt mange forhold, der gav mistrivsel og særligt mange forhold, der hæmmede deres mulighed for at opnå høj faglighed/viden.

Samtidig var den geografiske afstand til universitetet et udpræget problem for ph.d.studerende med bopæl langt fra SDU. Flere valgte pga. afstanden til arbejdspladsen at have mange hjemmearbejdsdage, og det havde flere konsekvenser: Man følte ikke den store tilknytning til arbejdspladsen eller fik ikke opbygget et godt/ordentligt netværk. Endelig er det tydeligt, at hensynet til familien vejer tungt for ph.d.studerende, der har børn/partner.

\section{Resultater: Interesse for en ph.d.-café}

Interviewpersonerne viste stor interesse for en ph.d.-café, og der var stor opbakning til biblioteket som vært. Alle så biblioteket som en oplagt og neutral arena, og man så det som en lettelse og en styrke for aktiviteten, at biblioteket kunne sikre en stabil afvikling.

Et cafétilbud blev set som en kærkommen mulighed for at møde ligesindede uden for ens egen forskergruppe, få flere informationer om bibliotekets services og også for at skabe kontakter på tværs af fakulteter. Det blev fremhævet som vigtigt, at caféaktiviteten blev et uforpligtende tilbud, men at det samtidig også har et fagligt ind-

\footnotetext{
${ }^{3}$ En mere uddybende gennemgang af de nævnte værdier kan rekvireres ved forfatterne. Derudover henvises til de grafiske kort i bilag 1
} 
hold, bl.a. for at legitimere den tid man som ph.d.-studerende skal bruge på at deltage i caféen.

Foreslået indhold på ph.d.-cafémøder var (i en ikke prioriteret rækkefølge):

- Biblioteksservices; fx informationssøgning, referencehåndtering, introduktion til databaser

- Arbejdsredskaber; fx NVivo og LaTeX

- Formidling; fx artikelskrivning, præsentationsteknik og populærformidling

- "Personlig udvikling"; fx motivation og planlægning, karrierevejledning

- Støttefunktioner

- Bredere oplæg om forskning og innovation

Mange ønskede oplæg og efterfølgende diskussion. Som supplerende form blev foreslået speeddating og også oplæg fra de ph.d.-studerende i konkurrenceform (ph.d.-cup). Flere ønskede desuden at kunne præsentere deres ph.d.-projekter.

\section{Konklusion på interviewundersøgelsen}

Undersøgelsens resultater peger på, at biblioteket med fordel kan udbyde en ph.d.café. For at være attraktiv for ph.d.-studerende er det - ud over at adressere nogle af de ph.d.-studerendes oplevede barrierer for et godt ph.d.-forløb - ifølge de interviewede ph.d.-studerende væsentligt, at ph.d.-caféen:

- Udbydes på tværs af fagområder

- Giver mulighed for både fagligt og socialt netværk

- Er et uforpligtende tilbud

- Afholdes inden for normal arbejdstid

Flere temaer var gennemgående barrierer for undersøgelsens deltagere, fx oplevet stort projekt og manglende kendskab til services og støttefunktioner, undervisning og ansættelsesvilkår. Nogle af disse er oplagte for biblioteket at adressere, andre vedrører (også) andre enheders indsatser.

Rundspørgen hos de andre universitetsbiblioteker viste, at der ikke var udviklet tilsvarende aktiviteter andre steder. Til gengæld viste de andre biblioteker stor interesse for konceptet, og flere har efterfølgende spurgt ind til vores erfaringer, da de overvejer at gå i gang med lignende events. Dette viser, at det ikke ligger fjernt for universitetsbibliotekerne at påtage sig en understøttende opgave som denne, hvor der bidrages til øget trivsel blandt en bestemt målgruppe. 


\section{Ph.d.-caféen: Status og evaluering}

I skrivende stund er ph.d.-caféen etableret, og de tre første mødegange afviklet.

Samtidig er der i biblioteket indrettet et fysisk område særligt dedikeret til ph.d.studerende og café-aktiviteterne. Emnerne hidtil har været: forskeruddannelse overordnet set, litteratursøgning og karriereudvikling. Vi har afviklet caféerne i en totimers ramme henover frokost, startende med ca. en times oplæg, hvor oplægsholder er opfordret til at gennemføre strukturerede netværksaktiviteter, fx bede deltagerne diskutere i mindre grupper. Herefter er der blevet serveret let frokost (sandwich) og de ph.d.-studerende har kunnet tale mere uformelt med hinanden. Yderligere en ph.d.-café er under planlægning. Denne vil have fokus på forskerstøttefunktioner og eksterne forskningsmidler. Særligt prioriteret i ph.d.-caféen er temaer, som vurderes at have appel på tværs af fagområder, som kan diskuteres på baggrund af (typisk) korte oplæg, og som de ph.d.-studerende i undersøgelsen oplevede som særligt barriereskabende at mangle kendskab til. Udvælgelsen af emner afhænger derudover af, hvad der kan lade sig gøre. Desuden er enkelte emner fravalgt, da de i forvejen varetages af ph.d.-skolerne og HR-service, fx undervisning/ universitetspædagogik. Senere forestiller vi os, at caféerne vil have temaer som ph.d.-studerendes retmæssige krav og rettigheder, den gode vejlederrelation, planlægning, stressforebyggelse og præsentationsteknik. Desuden vil der lejlighedsvist blive tilrettelagt events med ph.d.-studerendes egne projektpræsentationer - stadig i en tværfakultær kontekst.

Samtidig med ph.d.-caféerne er der opstået lignende aktiviteter (raw bars), planlagt og afviklet i biblioteket af de ph.d.-studerende selv, bl.a. gennem et tæt samarbejde mellem biblioteket og de ph.d.-studerendes nyligt etablerede interesseorganisation. Her har bl.a. præsentationsteknik været på programmet.

Det er vigtigt for os at evaluere temaer, oplægsholdere, tidspunkt på dagen m.m. for at optimere ph.d.-caféerne, så de forbliver relevante og tilgængelige for så mange som muligt. Vi vurderer løbende internt i arrangørgruppen tilbuddets succes ud fra antal tilmeldinger (målet til hver café er min. 20 tilmeldinger), gengangerfrekvens og aktivitet på de enkelte caféarrangementer (subjektive vurderinger i arrangørgruppen). Vi vurderer også løbende de forskellige fagområders repræsentation, da vi ønsker at tiltrække deltagere bredt blandt de ph.d.-studerende og holde fast $\mathrm{i}$ at give dem mulighed for at mødes på tværs af fagområder ( $f x$ gennem valg af oplægsholdere, emner mv).

Ph.d.-cafétilbuddet vil blive evalueret systematisk med deltagerne, når ph.d.-caféen har kørt det første års tid. De ad-hoc tilkendegivelser, vi har fået fra de ph.d.studerende hidtil (spontane mails), viser, at deltagerne ser tiltaget som en "super god mulighed", som de ph.d.-studerende gerne vil bakke op om, at caféen "klæder 
de ph.d.-studerende godt på til ph.d.-processen", samt at caféerne giver en "tiltrængt mulighed for at møde ligesindede", som man ikke gør i hverdagen på sit institut.

Fremmødet til ph.d.-caféerne har hidtil typisk været på 15-20 personer. Mundtlige tilbagemeldinger tyder på, at formatet opfattes som en ligelig fordeling mellem faglige og sociale input, således som der blev udtrykt ønske om i undersøgelsen. Også tidsrammen har virket passende; de fleste bliver her i de 2 timer som arrangementet varer.

Vi havde forventet, at særligt ph.d.-studerende fra de "tørre" fag ville benytte tilbuddet, da det er her, der typisk er størst problemer med oplevet ensomhed, jf. bl.a. Herrmann et al. (2014). Men det har vist sig, at der især kommer studerende fra de "våde" områder naturvidenskab og teknik. Det er endnu for tidligt at udpege årsager til dette, men en forklaring kan være, at ph.d.-studerende fra disse områder generelt har større fysisk tilstedeværelse på universitetet, og at det derfor praktisk set er nemmere for dem lige at smutte over på caféen. Desuden er det tydeligt, at ph.d.caféerne tiltrækker mange udenlandske ph.d.-studerende. Dette kan skyldes, at netop den gruppe har et begrænset netværk på universitetet, og måske derfor i det hele taget føler sig mere overladt til sig selv med deres ph.d.-projekt. Denne gruppe har vi dog slet ikke haft som del af undersøgelsen, af rene afgrænsningshensyn. Men de er naturligvis mere end velkomne på caféen, der af samme grund også afvikles på engelsk.

\section{Afrunding}

Det helt store problem for mange ph.d.-studerende er en oplevet ensomhed. Man kan måske sige, at ensomheden ligger $i$ et ph.d.-studies DNA, idet arbejdet med at udarbejde og forfatte en ph.d.-afhandling i sagens natur må ske på individuel basis. Men, som Herrmann et al. (2014) også peger på, så er årene, hvor man er indskrevet som ph.d.-studerende, også en dannelsesproces, hvor der sker en akademisk socialisering, som netop sker mest effektivt, når ph.d.-studerende føler sig som en del af et kollegialt miljø, hvor de betragtes som ligeværdige (fagpersoner). Det er derfor vigtigt at understøtte de ph.d.-studerendes sociale netværk - også på tværs af fagområder, da der her også sker en socialisering ind i en større akademisk kontekst, hvor de oplever at være del af hele den akademiske verden.

Man kan måske fortsat diskutere, om det overhovedet er et biblioteks opgave at etablere denne slags understøttende aktiviteter. Vi har i forbindelse med projektet inddraget universitetets ph.d.-skoler, særligt for at få kendskab til og dermed kunne undgå at komme til at konkurrere med evt. andre lignende aktiviteter. Vi har kun mødt opbakning til projektet; ph.d.-skolerne har generelt udvist stor interesse og bidrager løbende til markedsføringen. Fx distribueres invitation til de enkelte ph.d.caféer gennem ph.d.-skolerne, ligesom ph.d.-cafeen formidles på ph.d.-skolers op- 
startsmøder for nye ph.d.-studerende. Kontakten til ph.d.-skolerne er fortsat meget vigtig, og vi sørger for, at den løbende er til stede. Her hjælpes projektet også af, at biblioteket på SDU koordinerer universitets ph.d.-kurser i ansvarlig forskningspraksis, samt at vi i biblioteket også har et tæt samarbejde med det nyligt etablerede talerør for ph.d-studerende i national sammenhæng (PhD Association at the University of Southern Denmark - PAUSD). Udover opbakningen fra ph.d.-skolerne pegede de ph.d.-studerende (som tidligere nævnt) også på biblioteket som en naturlig arrangør, dels fordi biblioteket er neutral grund og kan sikre en kontinuerlig afholdelse; dels fordi biblioteket også er et tværfagligt sted, som opfattes at kunne facilitere mødet mellem forskellige fagområder.

Det er håbet, at universitetsbiblioteket ved SDU med introduktionen af de omtalte nye services for ph.d.-studerende kan være med til at hjælpe den nødvendige akademiske socialisering afgørende på vej, således at flere ikke bare gennemfører ph.d.forløbet, men også bagefter kan se tilbage på ph.d.-årene som konstruktivt formende år.

\section{Referencer}

Cooper, R. G. and Kleinschmidt, E. J. (1995). Benchmarking the firm's critical success factors in new product development. Journal of Product Innovation Management, 12(5), s. 374-391.

Danske Universiteter (2017). Forskeruddannelse Sektorniveau 2007-2016. Hentet d. 30. januar 2018 fra Danske Universiteters hjemmeside: https://dkuni.dk/tal-ogfakta/beredskab/.

Drachen, T. M., Larsen, A. V., Gullbekk, E., Westbye, H., \& Lach, K. (2011). Information behaviour and practices of PhD students. Hentet d. 30. januar 2018 fra The Free Nordic Arts and Humanities and Social Sciences Open Access Fulltext Repositorys hjemmeside: https://hal-hprints.archives-ouvertes.fr/hprints00599034/file/Information behaviour and practices of PhD students appendi ces.pdf.

Ernst, H. (2002). Success factors of new product development: a review of the empirical literature. International Journal of Management Reviews, 4(1), s. 1-40.

Gardner, S. K. and Mendoza, P. (2010). Part One: Setting the Context. Introduction. I: Gardner, S. K. and Mendoza, P. (Red.), On becoming a scholar: Socialization and development in doctoral education (s. 3-9). Virginia: Stylus Publishing.

Gutman, J. (1997). Means-end chains as goal hierarchies. Psychology \& Marketing, 14(6), s. 545-560. 
Gutman, J. (1982). A means-end chain model based on consumer categorization processes. Journal of Marketing, 46(2), s. 60-72.

Herrmann, K. J., Wichmann-Hansen, G. and Jensen, T. K. (2014). Kvalitet i ph.d.-forløb. Hentet d. 30. januar 2018 fra Aarhus Universitets hjemmeside: http://www.au.dk/fileadmin/www.au.dk/kvalitetiphd/KVALITET I PHD DA .pdf.

Miles, S. and Rowe, G. (2004). The laddering technique. I G. M. Breakwell (Red.), Doing Social Psychology Research (s. 305-343). Oxford: Blackwell.

Orsingher, C., Marzocchi, G.L. and Valentini, S. (2011). Consumer (Goal) Satisfaction: A Means-Ends Chain Approach, Journal of Psychology \& Marketing, 28(7), s. 730748.

Uddannelses- og Forskningsministeriet (2017a). Kvalitet i ph.d.-uddannelsen. Spørgeskemaundersøgelse blandt ph.d.-studerende og ph.d.-vejledere. Hentet d. 30. januar 2018 fra Uddannelses- og Forskningsministeriets hjemmeside: http://ufm.dk/publikationer/2017/kvalitet-i-ph-d-uddannelsenspoergeskemaundersoegelse.

Uddannelses - og Forskningsministeriet (2017b). Ph.d.-uddannelsens kvalitet og relevans. Sammenskrivning af hovedresultater. Hentet d. 30. januar 2018 fra Uddannelses- og Forskningsministeriets hjemmeside: http://ufm.dk/publikationer/2017/ph-d-uddannelsens-kvalitet-og-relevans.

Uddannelses- og Forskningsministeriet (2015). Ph.d.-uddannelsen i tal - udviklingen frem til og med 2013. Hentet d. 30. januar 2018 fra Uddannelses- og Forskningsministeriets hjemmeside: http://ufm.dk/uddannelse-oginstitutioner/videregaende-uddannelse/universiteter/ph-duddannelse/analyse-af-phd-omraadet\#.

Uddannelses- og Forskningsministeriet (2013). BEK 1039. Bekendtgørelse om ph.d.uddannelsen ved universiteterne og visse kunstneriske uddannelsesinstitutioner. Af 27/08/2013. Hentet d. 30. januar 2018 fra Det fælles statslige retsinformationssystems hjemmeside: https://www.retsinformation.dk/forms/r0710.aspx?id=152430.

Universitets- og Bygningsstyrelsen (2007). Undersøgelse af årsager til frafald blandt ph.d.-studerende. Gennemført af Epinion Capacent. Hentet d. 30. januar 2018 fra Uddannelses- og Forskningsministeriets hjemmeside: https://ufm.dk/publikationer/2007/undersogelse-af-arsager-til-frafald-blandtph-d-studerende-efterar-2007. 


\section{Bilag 1. Kort over interviews.}

Loesevejledning: Jo højere oppe i kortet, jo mere abstrakte konstrukter; nederst vises de konkrete navnte egenskaber ved ph.d.-studiet, i midten opfattede konsekvenser, øverst voerdier. Linierne angiver de kognitive forbindelser, dvs. at begreberne under interviewet er noevnt i en subjektiv (kausal) relation.'\%' angiver, at en associeret egenskab eller konsekvens af interviewpersonen blev oplevet som at have forhindret en vaesentlig vardi $i$ at blive udfoldet.

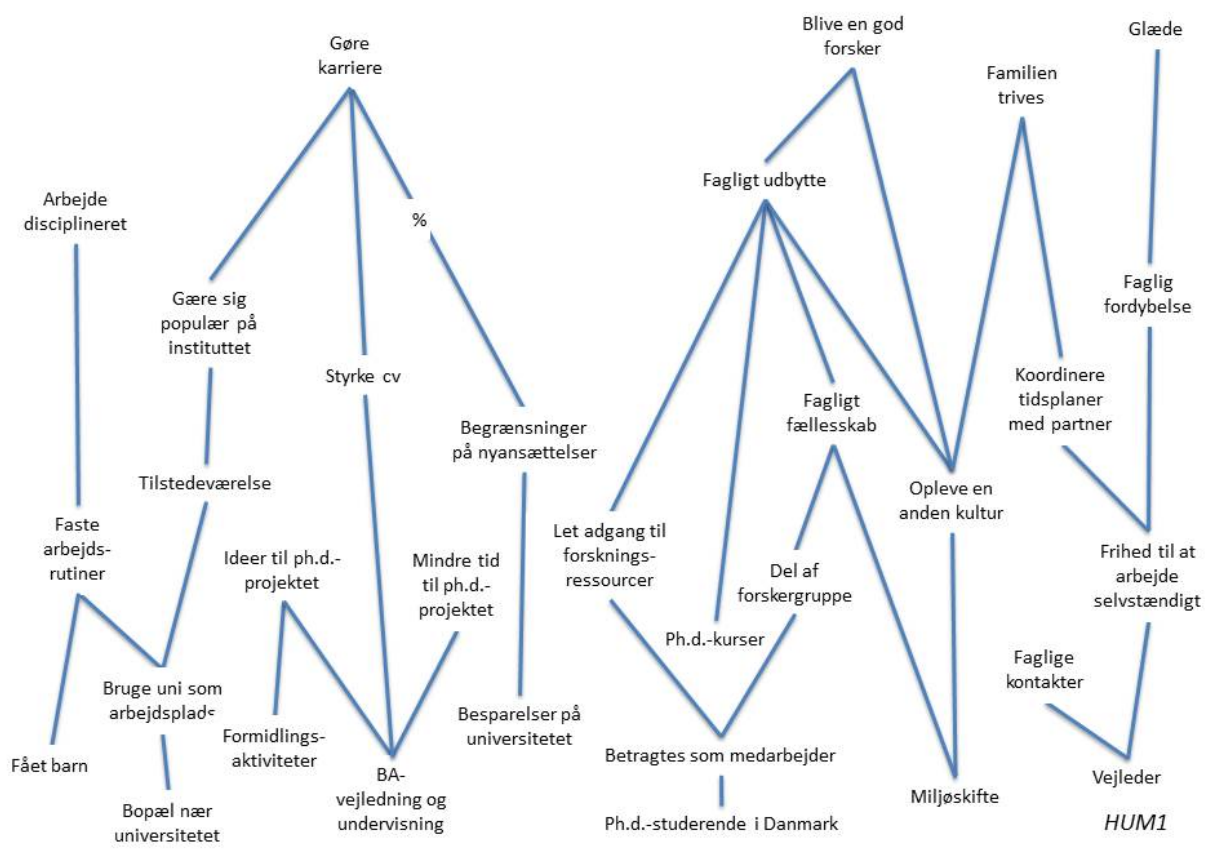




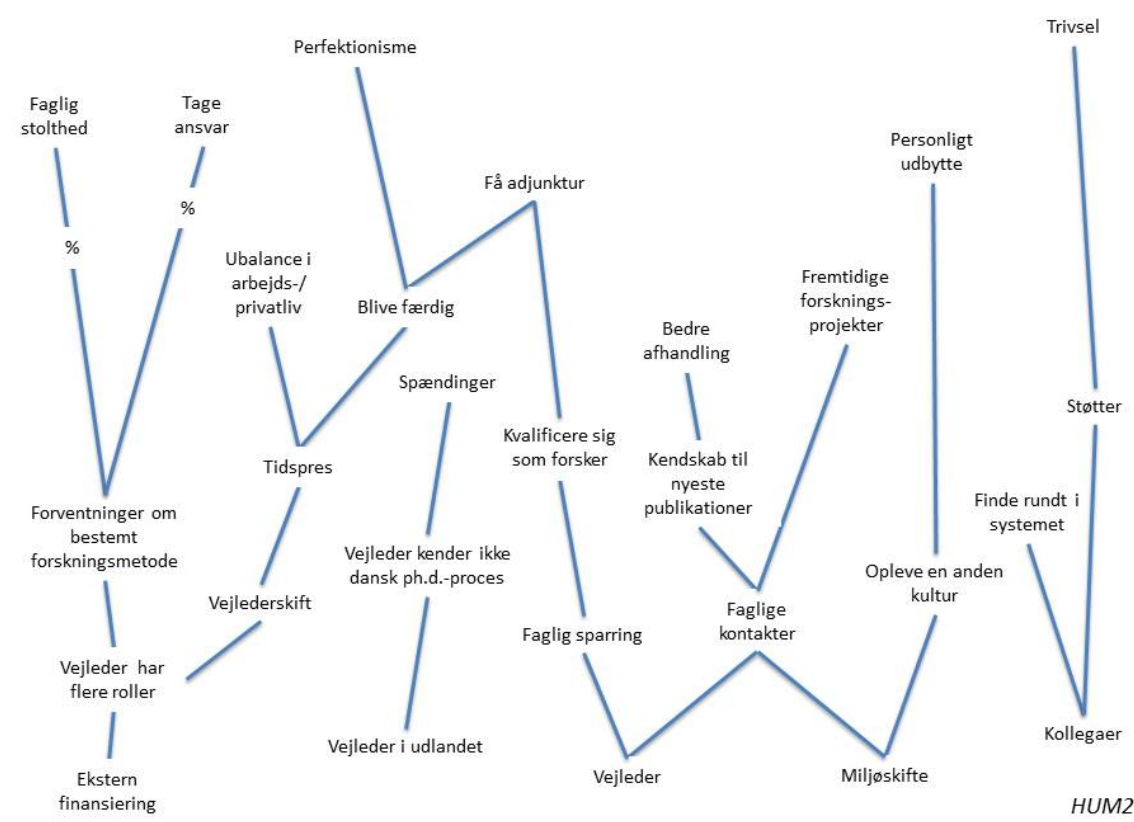

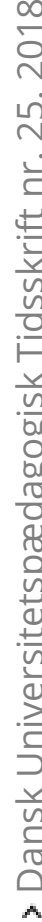

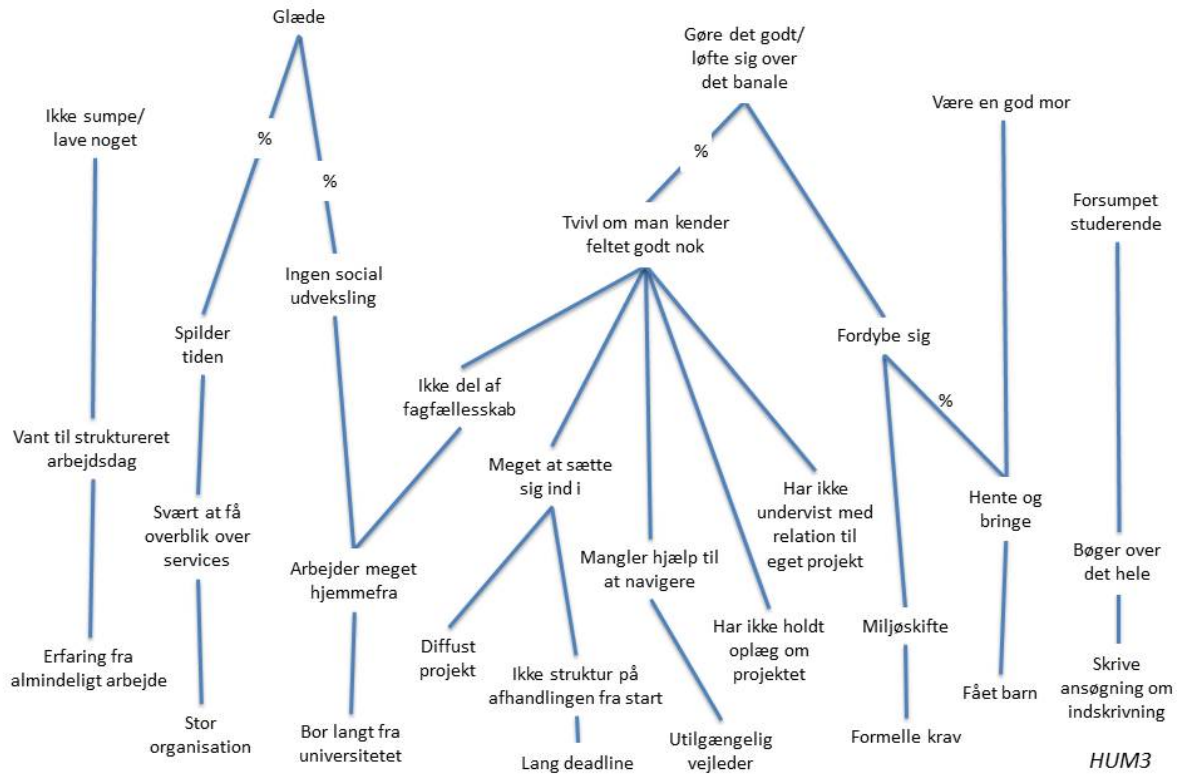



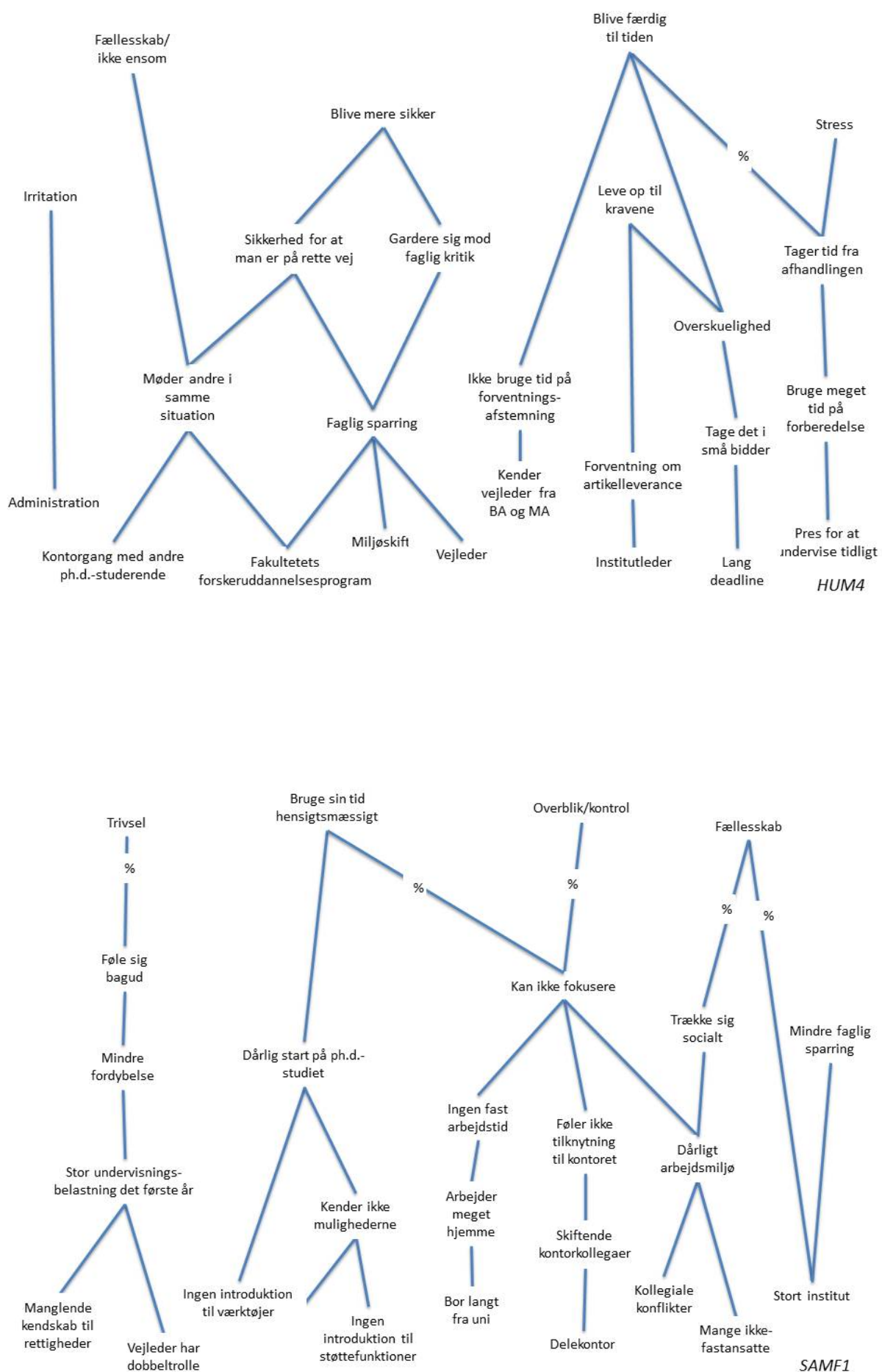

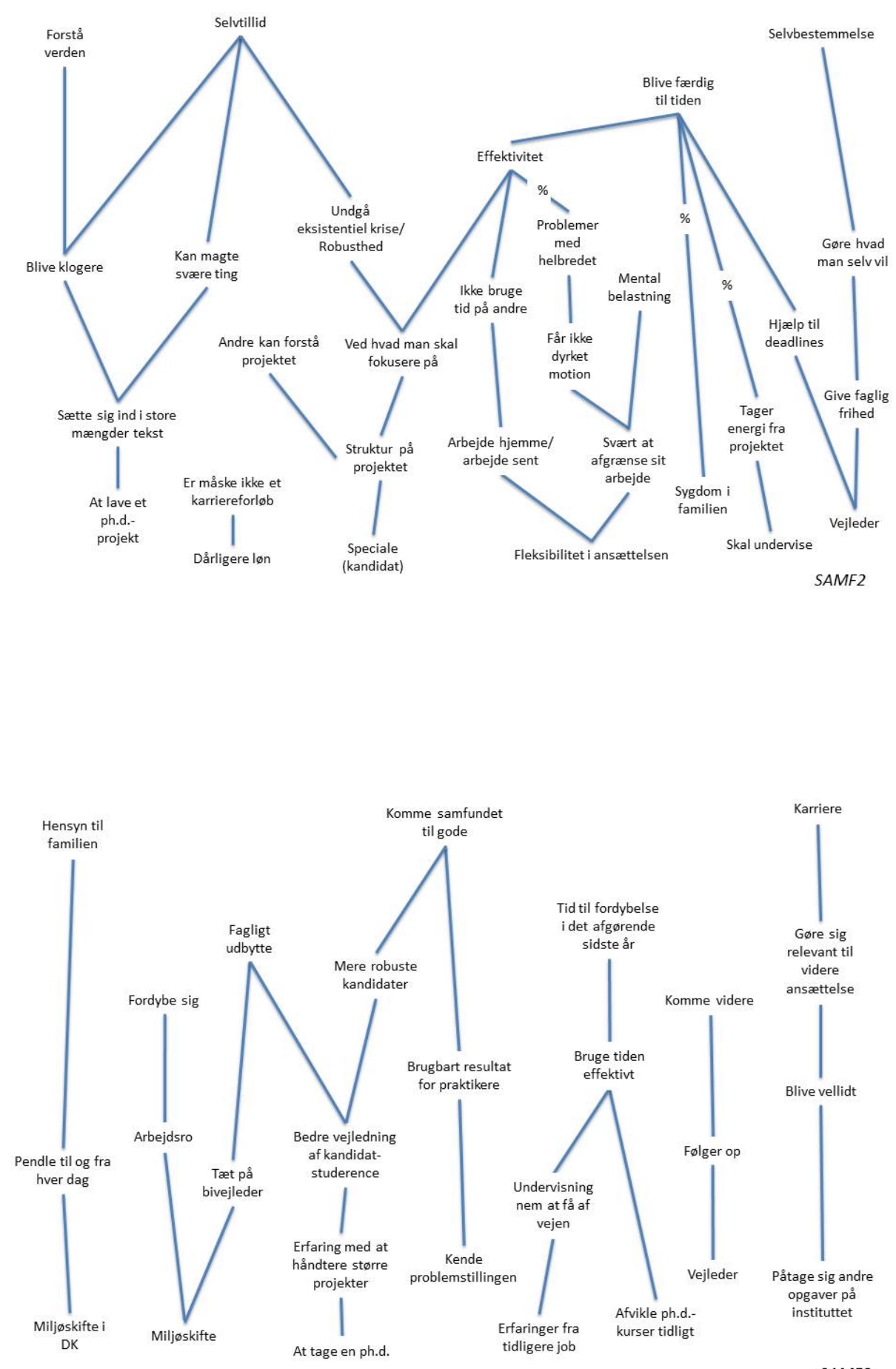

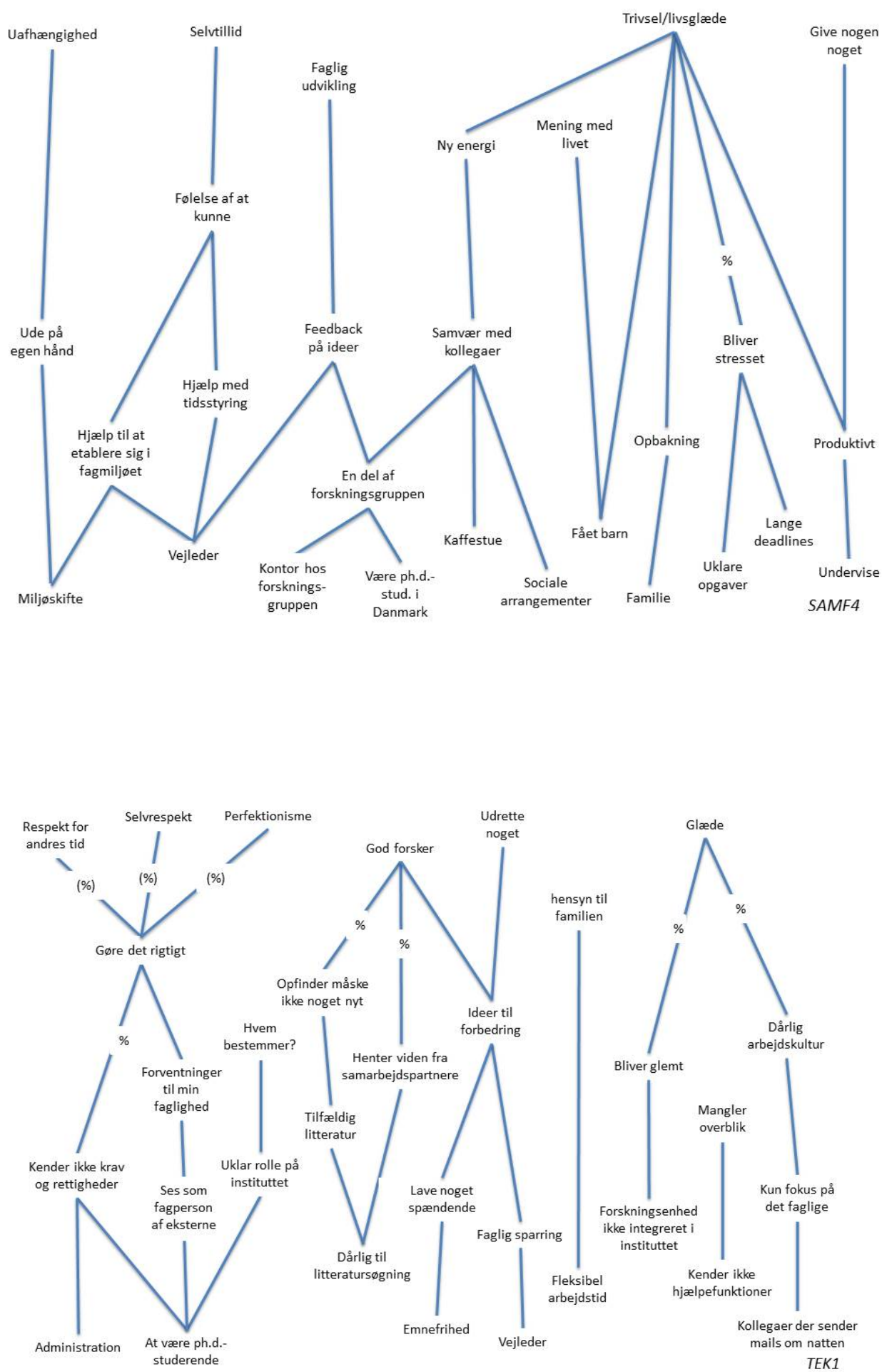


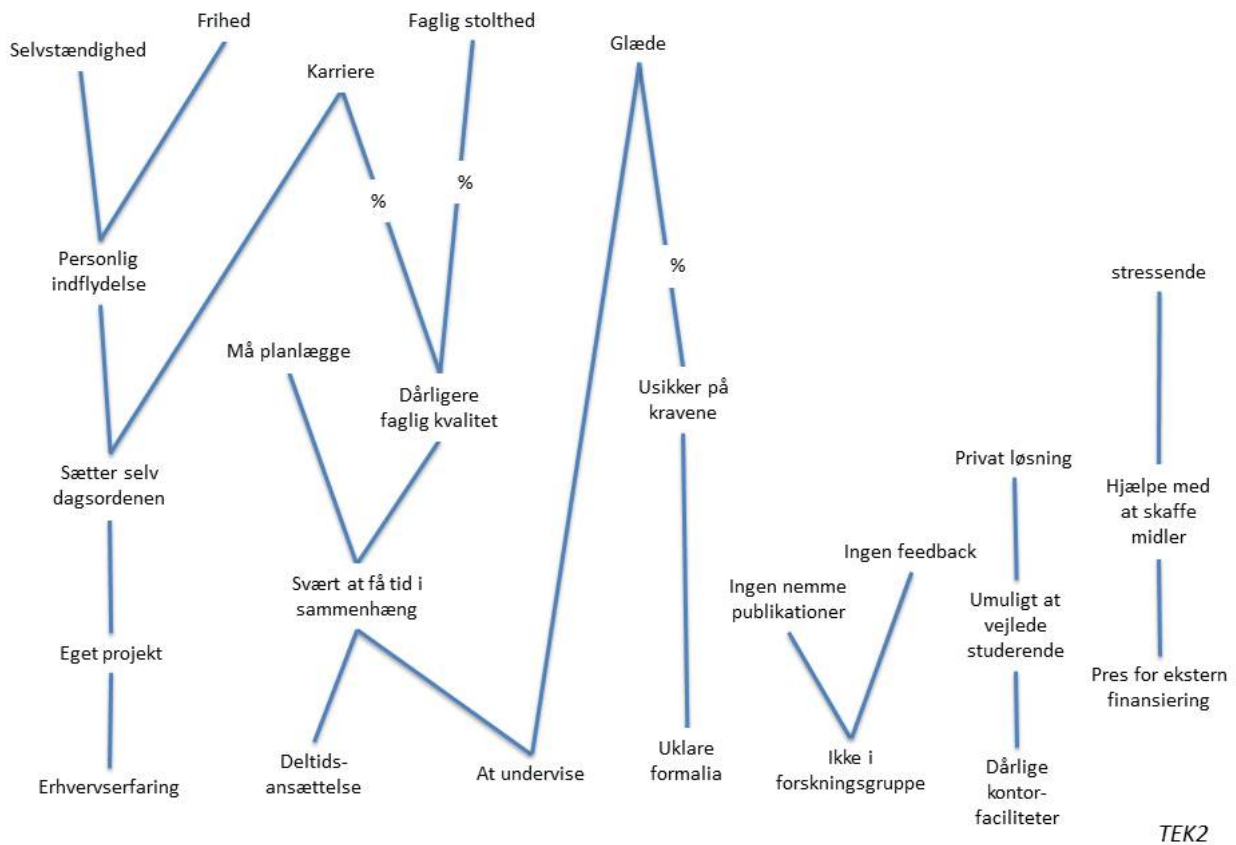

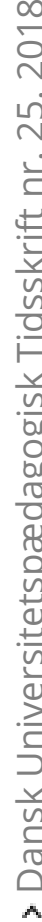

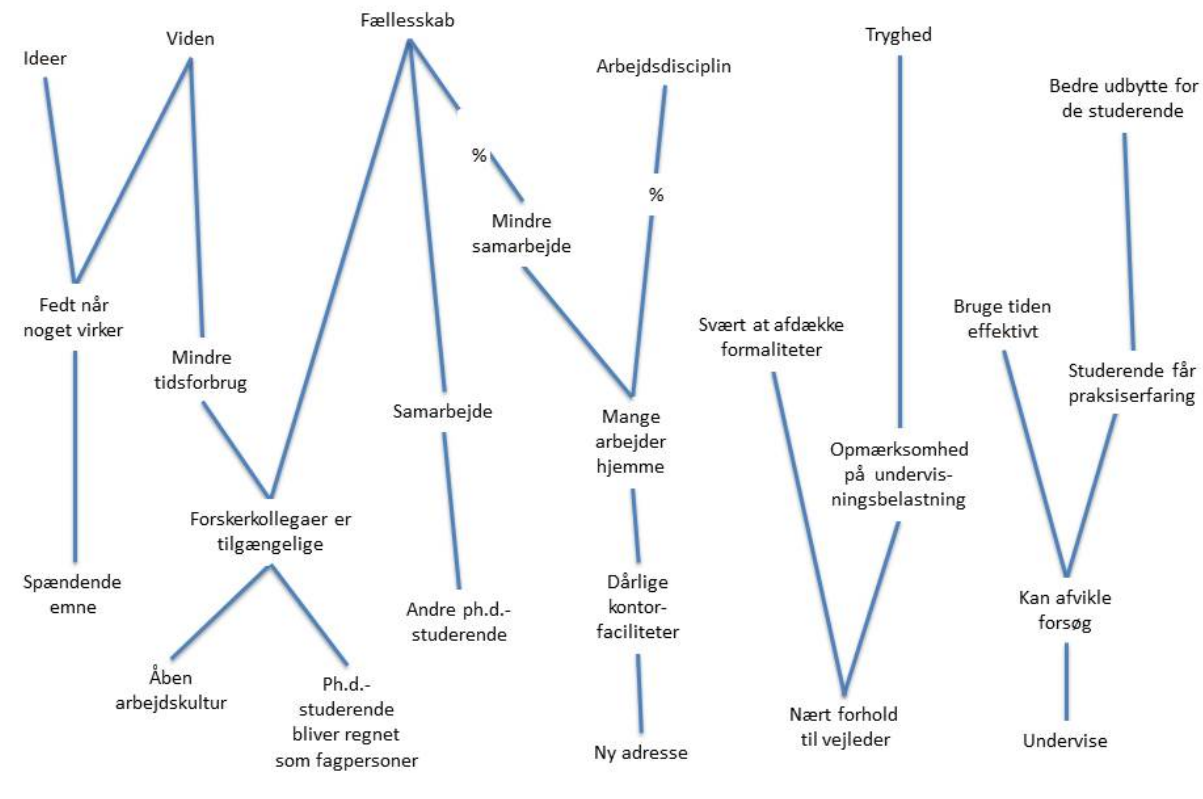




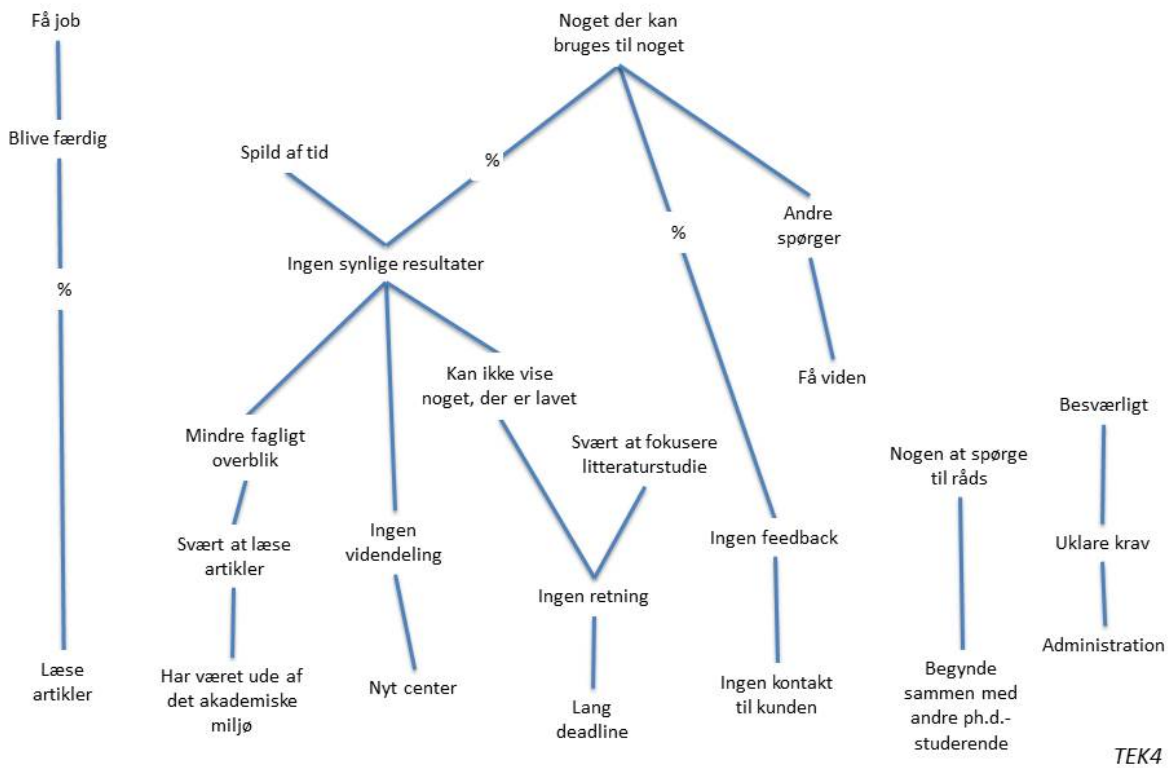

